\title{
THE AMBIVALENT AUTONOMY OF MOBILE “POCĂIȚI” BETWEEN VICOVU DE SUS, ROMANIA AND TURIN, ITALY AFTER 1989
}

\author{
CECILIA RUBIOLO 1
}

\begin{abstract}
Intra-EU labour migration literature is fairly limited within migration studies and it has seldom considered migrants' embodied experiences and processes of subjectivation as a constitutive element of translocal economic transformations. The present paper focuses on the popular economies enacted by a segment of the migrant working class moving from Vicovu de Sus in Suceava district, Romania to Turin, Italy after 1989 as entangled in the production of "neoliberalism from below" (Gago, 2015). Mobilizing oral histories collected during an ethnographic fieldwork undertaken between 2012 and 2013, I will present some aspects related to the fields of production and reproduction within the movements of migrants belonging to a pentecostal community affiliated to the Cultul Penticostal - Biserica lui Dumnezeu Apostolică. Pentecostalism is here understood as a performative regime of truth and practices (Foucault, 1987; Marshall, 2009), through which migrant bodies perform processes of subjectivation to actively "inhabit" the borders of the State and Capital. Bukovinean pentecostal discourse, through an entrepreneurial drive, a cultural shift towards material prosperity and a strict gendered division of labour, seems to have fostered the creation of a self-organized translocal community whose economic practices obey/re-enact rather than escape/re-signify the dynamics of exploitation and dispossession proper of Romania's peripheral incorporation into contemporary global regimes of production, accumulation and division of labour.
\end{abstract}

Keywords: intra-EU labour migration, post-communism, subjectivation, pentecostalism, neoliberalism from below

\section{Introduction}

Contemporary literature concerned with Central-Eastern European intra-EU labour migration ${ }^{2}$ is fairly limited if compared with research undertaken about incoming flows of labour from extra-European countries. It is possible to distinguish

1 Independent researcher, email: rubiolo.cecilia@gmail.com.

2 See, for instance, Favell and Nebe, 2009; Meardi, 2012; Stan and Erne, 2013; Woolfson, 2007. 
a " 'social dumping' perspective, which sees intra-EU labour migration as unsettling of existing industrial compromises in Western Europe" from an "integrationist' perspective, which sees migration as beneficial to economic growth prospects" (Andrijasevic and Sacchetto, 2016: 1). Both hold the limitation of often neglecting migrants' embodied experiences ${ }^{3}$ (Papadopoulos, Stephenson and Tsianos, 2008) as "a constitutive and antagonistic element of the capital relation" (Mezzadra, 2010). Partially in resonance with the perspective proposed by the theory of the autonomy of migration (Moulier Boutang, 1998; Mezzadra, 2010; Mitropoulos, 2007; Papadopoulos, Stephenson and Tsianos, 2008), I would on the contrary stress the epistemological and political importance of accounting for migrant subjectivities not merely as products of the functioning of State and Capital, but as co-constitutive of the current intra-European border regime pivoted on a logics of differential inclusion of migrant labour (Mezzadra and Neilson, 2013; Rigo, 2007).

In her analysis of "popular economies" 4 in Argentina as a new frontier for strategies of capital accumulation and processes of financialization after the 2001 crisis, Verónica Gago introduced the concept of "neoliberalism from below".

By neoliberalism from below, I am referring to a set of conditions that are materialized beyond the will of a government, whether legitimate or not, but that turn into conditions upon which a network of practices and knowledges operates, assuming calculation as its primordial subjective frame and functioning as the motor of a powerful popular economy that combines self-managed community knowledges and intimate know-how in the crisis as a technology of a mass self-entrepreneurship [...]. [S]peaking of neoliberalism from below is a way of accounting for the dynamic that resists exploitation and dispossession and at the same time assumes and unfolds in this anthropological space of calculation, which is in turn the basis for an intensification of that exploitation and dispossession. (Gago, 2015: 14)

It seems fruitful to mobilize such a concept, which stems from a foucauldian analytics of power (Foucault, 1976:121-123), in the understanding of certain intra-EU migration movements as an "everyday 'realization' and transformation" (Bayart, 2008:17) of a neoliberal politics of transnational labour mobility (De Genova, 2016). Firstly because it focuses on its everyday embodiment by popular subjectivities, rather than simply on macro-rationalities, calling for broader conceptions of the political and the economic; secondly, because it insists on the

${ }^{3}$ For instance, Stan and Erne's noteworthy contribution focuses "on the role played by post-socialist transformations of production regimes, and the particular modes of development that resulted from them, in the specific shape taken by east-west migration at different points of time" (Stan and Erne, 2013: 3). On the other hand, qualitative and ethnographic research, for instance Anghel (2013); Bleahu (2004); Elrick and Ciobanu (2009); Horvath (2008); Potot (2000); Radu (2001); Vlase, (2004), is rich in accounting for migrants' everyday life, but is often limited in the analysis of its entanglement with capitalist forms of valorisation.

${ }^{4}$ Referring to self-managed subsistence labour forms practiced by poor sectors of the urban economy. 
radical ambivalence of popular economic practices, characterized by a complex coexistence of flight and capture with respect to mechanisms of capitalist subsumption. I will discuss the autonomous ${ }^{5}$ labour practices enacted by a peculiar segment of the migrant population who moved from Vicovu de Sus, Suceava district, Romania to Turin, Italy after 1989 , as a strategic site where to inquire into the dynamics of "neoliberalism from below". Specifically, I will look at labour migrants belonging to a pentecostal translocal community affiliated to the Cultul Penticostal - Biserica lui Dumnezeu Apostolică ${ }^{6}$. On a theoretical level pentecostalism, understood as a religious and intrinsically political discourse, can be defined as a performative regime of truth and of practices (Foucault, 1987 and Marshall, 2009) which constantly participates in the reshaping of imaginaries and subjectivities in relation to the borders of the State and of the Capital. Within the pentecostal discourse what is at stake is precisely the constant negotiation of the relationship between the self and the surrounding order through "processes of moral subjectivation whereby 'individuals or communities constitute themselves as subjects at the margins of constituted knowledges and established powers, even if this means giving rise to new knowledge and inspiring new powers' (Deleuze, 1990)" (Marshall, 2009:34). Much has been written about the relationship between pentecostalism, migration and the economic, from divergent perspectives and within different socio-political contexts ${ }^{7}$, for instance insisting that pentecostal churches pushes migrants towards "a modern engagement with the market on its own terms; social catapulting as a motivational force that results from this particular ethic and that puts into motion particular group dynamics" (Van Dijk, 2009: 111). However, contemporary social research seldom focused on mobilities and markets crossing the post-communist Eastern European spaces (Wanner, 2007) ${ }^{8}$.

Mass-emigration from Romania (6-7\% of the total population) started during the second half of the 1990s, a phase of devastating social consequences derived from a political economy defined as disembedded "shock therapy" neoliberalism $^{9}$ (Ban, 2011), and the main destinations were Italy and Spain. The two countries came to account for $60 \%$ of total number of emigrants after

${ }^{5}$ In the sense of self-organized.

${ }^{6}$ The only pentecostal movement to have received formal recognition from the State as a Cult. However, it is possible to speak of an effervescence and an informalization of Pentecostal/evangelical movements in the post-communist context. The 1992 census registered 219.151 pentecostals, while the 2011 one 367.938 , that is $1,92 \%$ of the total population. Since 1989 pentecostalism has known the highest growth rate among all religious movements in Romania.

${ }^{7}$ See, for instance, Aubrée, 2003; Van Dijk, 2002; Huwelmeier and Krause, 2009.

${ }^{8}$ On different aspects of the pentecostal movements in Romania, but not focused on migration, particularly interesting are Foszto, 2009; Foszto and Kiss, 2013; Gog, 2012.

${ }_{9}^{9}$ At the end of the 1990s wage levels had halved with respect to 1989 (in Euro equivalent), while poverty had grown from $20 \%$ in 1996 to $36 \%$ in 2000 , since the average monthly net wage had decreased from 187 euros in 1989 to 107 euros in 2000 (see Stan and Erne, 2014:12). 
2002, in concomitance with the possibility of visa-free entry to the Schengen area for Romanian citizens (Ban, 2009) ${ }^{10}$. Labour migration as a subsistence strategy within a context of rising unemployment and poverty can rightly be interpreted as a productive component of Romania's post-communist neoliberal trajectory of economic integration within transnational capitalist circuits (Stan and Erne, 2014). Within such historical context, Romanian pentecostalism as embodied by post-communist migrants moving between Vicovu-de-Sus and Turin, fostered the foundation of a "whiter" (Țichindeleanu, 2011; De Genova, 2016) entrepreneurship along with a conservative gendered division of labour as the motor of holy translocal economies. It would be mistaken to interpret such economic practices simply as "autonomous" acts of resistance or survival within a neoliberal regime generated from above. Instead their ambivalence lies precisely in that they are generated within and through neoliberal practices and knowledges, hence it becomes important to pay attention to everyday material migrants' subjectivation processes (Lüdtke, 1995).

\section{Vicovu de Sus, the establishment of a pentecostal migratory chain}

Vicovu de Sus is since $2004^{11}$ one of the 11 "orașe"12 of the Suceava province and it is situated in the historical region of Bukovina ${ }^{13}$, a borderland which has historically been subjected to several processes of conquest and colonization since the Austro-Hungarian rule (Beaumont, 2005). Vicovu de Sus administrative unit also comprises the ex village of Bivolărie. It is situated $6 \mathrm{~km}$ away from the Romanian-Ukrainian border. According to the 2011 INSSE census it counts 13.308 inhabitants, mainly Romanians (12.347), with a small Roma community (268), among which $2.872^{14}$ declare themselves pentecostals (insse.ro). Under the Communist regime, Suceava's district was the last one to be officially collectivized in 1962 (Iordachi and Dobrincu, 2009). In Vicovu de Sus, whose local society was composed mainly by peasants and structured along ethnic lines, the first CAP

\footnotetext{
10 See, for instance, Anghel, 2013; Ban, 2009; Diminescu, 2003; Horvath, 2012; Ricci, 2005; Sandu, 2006; Serban, 2011; Sigona, 2011; Toma, 2012.

11 Law 83/2004.

12 "Oraș" is the equivalent of "town". On an administrative level the Romanian State is composed of municipalities (comune), towns (orașe), cities (municipii) and counties (județe).

13 Today Romanian Bukovina, to distinguish it from Ukrainian Bukovina from which it was separated through the Paris Peace Treaties in 1947.

$1421,6 \%$ of the total population.
} 
"Unirea" 15 was created in March 1962 to employ a great segment of the population. Another segment was employed in the construction sector, in wood processing, in the extractive industry and in metal processing ${ }^{16}$. During the last decade of Ceaussescu's regime, parallel to the official economy, there was a spread of consumption-driven informal economic activities (Chelcea, 2002), which in Vicovu de Sus developed mainly through self-entrepreneurial activities in the realm of tailoring, tanning and shoemaking. After the "peripheral incorporation of the post-communist region after 1989 into contemporary global regimes of production, accumulation and division of labour" (Poenaru, 2013), with the shift towards a capitalist market economy, Romania was the theatre of a political economy of land de-collectivization. The controversially conceived and implemented Law nr. 18/1991, called Legea Fondului Funciar ${ }^{17}$ (Verdery, 1996), also had a strong impact on the local economy in Vicovu de Sus.

In order to make a living and subsist, the inhabitants of the town were forced to follow one of the two alternatives or both. Taking advantage of freedom of movement across borders and the possibility of obtaining employment contracts in other countries, some of the inhabitants of the town have dedicated themselves to business activities elsewhere or have become occasional traders dedicated to the sale of certain products. Another part of the residents opened trading businesses, or went into production and services in the municipality. (Unsigned monography on the history of Vicovu de Sus, unknown year of publication)

Together with the process of de-collectivization, the post-communist condition was marked by a time of privatizations and wild neoliberalization, which in North-Eastern Romania caused the steadiest increase in unemployment (in 1999, 14,9\% of the population against a national average of $11,6 \%$ ). Selfentrepreneurship and translocal migration where the main economic tactics undertaken by the local population, both with a great impulse from the local pentecostal community.

The pentecostal community in Vicovu de Sus is organized in four churches, belonging to the Pentecostal Cult ${ }^{18}$ :

- Biserica penticostală Numărul 1 in Vicovu de Sus, founded in 1918. In

15 C.A.P. stands for "Colective agricole de producție" and it refers to the collective farms established through a program of agrarian reform promoted by the communist regime between 1949 and 1962.

16 Data published in the only existing monography about the history of Vicovu de Sus (unsigned manuscript unknown year of publication, received by the author via e-mail from the Vicovu de Sus local government (Primaria) on 29/10/12).

17 Law on Agricultural Land Resources.

18 There is also a community of "dissidents". 
$2013^{19}$ it counted 1.000 registered members and 250-300 people in the diaspora;

- Biserica penticostală in Laura, founded in 1986, with 300 registered members;

- Biserica penticostală Betleem in Bivolărie, founded in 2000, with 600 registered members;

- Biserica penticostală in Plai, a Roma "mono-ethnic" church founded in 1999, lead by Romanian members belonging to the Biserica nr. 1, with 50-80 adults attending church events ${ }^{20}$.

The history of the community begins at the end of World War I, by initiative of Nișu Constantin, who was returning from the Russian front and founded a pentecostal congregation with Russian influences (Andreiescu, 2012). The genealogy of the pentecostal discourse in Bukovina, which is considered the most conservative in the whole country, is linked to the history of Molokans, a mystic movement born during the second half of 16th century (Wanner, 2007), but also the Amish, the Mennonites and the Baptists, as it was explained to me by Simion Buzduga, one of the most respected pentecostal theologists in the Suceava district:

The origins of pentecostalism in Bukovina have to be retraced to Germany. In Bukovina, Rădăuți was the most germanised place, there were not many Anabaptists, but many Amish and Mennonites. They didn't accept modernism. So this was the first influence. The second influence was baptism. But overall we can say that the pentecostal movement saw a great influence from Saxons, who came back after WWI. There is no relationship here in Bukovina with pentecostalism in the USA. In fact, pentecostalism existed in Russia before the USA. In the second half of the 1800, in Armenia there were believers. In Russia the experience of the Pentecost goes back to the second half of the 19th century. (Simion Buzduga, october 2012)

The social and economic conditions of the first converts in Vicovu de Sus where those common to poor peasantry and conversions occurred by family units. The pentecostal community historically suffered great institutional repression. First, during the interwar period in the context of a growing nationalism (Livezeanu, 1995), when a specific State-Church relationship was prefigured, so that the Orthodox and the Greco-Catholic Church obtained the status of "national churches" (Lavinia Stan and Turcescu, 2007; Foszto and Kiss, 2013). Under the Antonescu regime pentecostalism and other religious minorities where also harshly persecuted as enemies sects. The communist regime, on the other hand, recognized a Pentecostal denomination in 1950 to centralize neo-protestant

\footnotetext{
${ }^{19}$ Fieldwork data.

20 Based on an interview with Vasile Ionesi, responsible for the church, member of Biserica penticostală Numărul 1.
} 
activities and better control the movements ${ }^{21}$. Such repression didn't stop the growth of the movement and it is precisely in such a context that the local community nourished a strong culture of economic self-organization and entrepreneurship beyond state control, which was then mobilized with the integration of the local economy within socialist structures. During the 1990s the main economic activities in Vicovu de Sus were shoemaking, tanning, tailoring, construction, retail trade, wood processing, transport, automobiles, with the leading sector being shoemaking and linked industries (especially tanning). After 1989 more than a hundred shoemaking enterprises appeared, most of them really small or medium size. In time, most of the production concentrated in the hands of a few factories, among which the most successful were the ones owned by members of pentecostal churches, namely Marelbo, Nicolis, Lidoro Prod Com and Incar Prod Com. According to the mayor, in 2013 the shoemaking industry employed 2,000 people.

In Vicovu de Sus labour migration flourished during the Ceaușescu regime, both on an inter-regional level, with seasonal mobilities towards western Romanian regions to work in CAPs and in mines, and on a transnational level, mainly towards the United States. Migration from Romania to Italy became consistent after 1989; however, there are no reliable statistics about it, since the majority of the movements were not regulated ${ }^{22}$. It is nevertheless widely recognized that migration from Romania to Italy, and to Turin specifically, became more relevant since the mid-1990s (Sacchetto, 2011), as a common class experience (Kalb and Halmai, 2011) of the ex-communist working class, dispossessed along different gender and colour lines during post-communism (Kideckel, 2008). As it has been argued,

[i]n 1989 in Romania, 28\% of the population was employed in agriculture; during the two following years the percentage rose to $40 \%$. The land saves a segment of the population through subsistence economy, but it can no longer be a permanent resource to which to entrust oneself on the medium and long term. The major route towards emancipation from living in the moment thus becomes emigration. (Sacchetto, 2011: 25)

\footnotetext{
${ }^{21}$ Although it was a religion recognized by the State, the Pentecostals were considered by the staff from the Department of Religious Affairs as «an infection», «sickly mysticism», " fanatics», «bigoted» and against culture. See Neagoe-Pleșa and Pleșa 2005.

22 "The major problem encountered here is that (similarly to other sending countries) Romanian authorities have few tools to induce the (de)registration of emigrants. If we compare the Romanian emigration statistics with the immigration statistics of the main receiving countries, the results will be shocking. According to the World Bank statistics, in 2010, 2,8 million Romanian citizens resided abroad. In the time period between 2001 and 2011, the number of emigrants registered by the Romanian authorities was just about 128,000 persons. If we look at the flow statistics of the main host countries, we will realize that the Romanian emigration statistics captures less than 10 percent of the legal outflows from Romania" (Kiss 2013:6).
} 
In 1989 in Italy there were 8,000 regular migrants, in 1999 - 50,000, and over 100,000 in 2002 (Carfagna and Pittau, 2003). Given the fact that the main instrument through which migratory movements were managed in Italy at the time were the so called "sanatorie" 23 in the absence of any coherent migration policy, the crossing of national borders occurred illegally, and was followed by an irregular insertion in the labour market (Reyneri, 1998). Most of the immigrants were integrated into the local labour markets through low-skilled jobs in the agriculture and service industry, a fact that was typical for migrant labour in Italy, which was "characterized by employment in heavy, low-qualified, unhealthy and underpaid jobs" (Ferrero and Perocco, 2011: 16-17).

According to the testimonies I collected, the first migrant from Vicovu de Sus to Turin, I. B., left in 1993. He was followed by his brother and a few others, for a total of around ten people in the first half of the 1990s. The phenomenon took of between 1995-2000, with a significant feminization of the migratory movement starting from the end of the decade, when many women left their families in order to integrate into the service and care economy in Italy. Turin was chosen as a destination because back in the 1980s and 1990s it was known as the "city of FIAT". It was represented as a flourishing industrial city with good economic opportunities, an imaginary which soon collapsed in front of the migrants' eyes.

The Romanians who were the first to go out of the country were the pocăiți. In fact we were all over the world, we went everywhere. We went to the USA and to move around we used the power of the Faith, our love. We all knew each other. (G., august 2013)

Pentecostal migration, which was driven by economic reasons, was also charged with prophetic meaning, linked to the will of God and the Holy Spirit, "who showed us the way", and a missionary one, linked to the moralizing role that the members of the church felt they held in Turin, a context represented as corrupt by ultra-worldly values.

In Vicovu we are closer to the Spirit, and we bring it to you, we bring Salvation. (L, january 2013)

I asked God: “Lord, I am missing a job". First I wanted to go to the USA, with documents, everything legal... If I am not legal some nasty things can happen to me. In the USA I didn't go because the Lord told me not to. Then a brother had a prophecy, a spiritual gift: "Look, you have to go to Turin". Because he saw a vision with the map of Italy and Turin he saw it. He saw a map with an I, like Israel and Italy, but I thought of Italy and Turin and so I started to do all of those things, to arrive there as a tourist. (N., January 2013)

23 "Sanatorie" are large scale amnesties, through which, from mid-1980s, irregular migrants were cyclically legalized in Italy. (Colombo and Sciortino, 2004) 
Pentecostals were pioneers in moving outside the region during communism to seek for job opportunities. As far as the movements towards Turin are concerned, other than fuelling such entrepreneurial spirit, the church represented a central infrastructure for the migratory projects.

How could you put together 1,500 German marks? How could you? There were maybe ten of us in the family... my father worked and we worked too. So what happened is that the church collected the money for my brother to leave. We do it now regularly as they did it for him and for others. (L, January 2013)

Another aspect was linked to the relationship with the pentecostal communities in the destination countries, for example in Turin a contact was established with the Assemblee di Dio. It was a guarantee that the migrant would have some support and orientation once arrived. Finally, through the pentecostal network it became possible to organize a very flexible structure of migration, both enabling the establishment of strong links with the community of origins and the possibility of return migration, both encouraging temporary labour mobility all over Europe, according to the conditions of local labour markets.

\section{An army of autonomous workers in Turin}

It is important to underline that the "governmentality of migration" is in fact "primarily a government over lives" (Tazzioli, 2013: 86), which functions through the production of differences (in juridical conditions and beyond) which are put to value in contemporary capitalism, creating different regimes of life related to the position that is assigned to such differences within a given political order. The government of lives moving between Vicovu de Sus and Turin can be interpreted as being built upon the intersection between two governmentalities.

The first governmentality is related to the re-defined concept of postcommunist "transition" (Gunder Frank, 1991) which crosses "oriental" territories and bodies since 1989 and which can be synthesized with the words of decolonial philosopher 0 . Tichindeleanu, who argued that " $[t]$ he political meaning of transition/integration/accession is therefore the top-to-bottom alignment of East European governmentality in the order of Western governmentality, and of local economies into the world system of capitalism" (TTichindeleanu, 2010: 26). Such governmentality is related to the economic process of "Third-Worldization" of the so-called "Second World" about which A. Gunder Frank already spoke as 
early as 1992 and it deploys itself since the end of "State capitalism"24 in 1989 (Tamás, 2009: 11-28) through a series of technologies meant to pathologize/ infantilize/allochronize/feminize "backward" post-communist oriental bodies and territories with respect to the "civilized" western capitalist democracies. Transition in this context is translated into a "new" mode of production and accumulation, a "socially-disembedded" (Ban, 2011: 348) form of capitalism, that is neoliberalism. The second governmentality is related to the contemporary European regime of migration control, inextricably linked to the changes occurring in the management of internal and external borders both in the EU and in the Schengen Area (Rigo, 2007). Such a regime doesn't work along the dichotomous lines of inclusion/exclusion upon which the modern discourse of citizenship was built, but instead it deploys itself through multiple and violent temporal and spatial processes of differential inclusion (Mezzadra and Neilson, 2013) which produce the conditions of segmentation of the migrant labour force to exploit its power within highly hierarchic labour markets (Ferrero and Perocco, 2011).

Within the pentecostal community in Turin, migrant bodies gendered as males coming from Vicovu were mainly employed into four different economic sectors: construction, small business, transportation and handicraft. More precisely, the vast majority was self-employed, holding a "partita IVA" 25 as bricklayer; a minority was salaried with different duties within the "Tarsin" transportation enterprise; two people were employed as electricians and one as a plumber.

Males work mostly in construction and factories. Either they hold a VAT or they are salaried. [...] The second generation changed a little. Some males are working as mechanics and others are also in factories. Then we must say that there are different situations, because now the parents support their children through school to study, while the first generation has other difficulties. [...] From Vicovu, men work primarily in construction, holding a VAT, then there are craftsmen, two or three, always with the VAT, and people working in transportation, two or three. There are also two electricians. But the main thing is the construction sector. Almost all males in the church work in construction. Some now went back to Romania and opened there a company with the skills they have learnt here in Turin. Because here with the crisis the sector shrunk... Now the biggest enterprise in the building sector within the church is [...], which has 12 employees. $70 \%$ of men of the church work in construction [...]. There are about thirty people owning companies who take others in the church to work. (A., March 2012)

The structural economic context in which migrants from Vicovu de Sus found themselves was characterized by long-term effects of the profound crisis affecting the binomial "FIAT-Turin" since the early 1970s. Turin in the 1990s

24 See also Polgár (2012).

25 The Italian name for VAT number which is the registration code to work as self-employed. 
was no longer a "company-town". On the one hand FIAT's productive model had been profoundly reorganized through a growing financialization, a policy of saving on labour costs, a transformation in the relationship between the enterprise and the linked industries and the delocalization of the production both in Southern Italy and abroad. On the other hand, in terms of employment this resulted in the primacy of the service sector over the secondary one which however couldn't compensate for the overall unemployment of about 65,000 former employees ${ }^{26}$ (Castagnoli, 1998). The high level of unemployment affected mostly the less educated segments of the workforce. In fact, during the 1990s and at the turn of the century, Turin's urban economy was profoundly reconfigured in terms of an expansion of service industries, also called the "industrial metamorphosis" (Berta, 2007): "Turin shares with other North-Western metropolises a trend that, during the thirty years comprised between 1971 and 2001, saw its industrial workforce halved" (Cominu and Musso, 2009: 45). The migrant workforce in the 1990s thus entered a post-fordist productive system where, on a regional level, there was a high demand for

unskilled industrial workers and construction workers, but also of manual workers in the service sector and domestic workers [...]. For males, the construction sector and the small enterprises have represented many opportunities for employment, especially in the initial phase of insertion. (IRES Piemonte and Fieri, 2011: 113-115)

In a seminal research published in 2000, concerning the employment of male immigrant workers, Allasino argued: "Work in the construction sector and in small and medium manufacturing enterprises dominates among males" (Allasino, 2000: 22). At the time of arrival of the fist pioneers from Vicovu, the construction sector in Turin was organized in a similar way to other Italian urban contexts, with the proliferation of small enterprises and the use of subcontract mechanisms.

As mentioned, the pioneer pentecostal migrants coming from Vicovu de Sus entered the labour market in Turin primarily within the construction sector, already before 1995. It was mainly a "job on call", illegal, for local small enterprises. If the crossing of the Italian State borders often occurred illegally or via tourist visas, through the intermediation of "passeurs" from Marginea, the insertion within the local labour market occurred through the intermediation of

26 "In the transition from Fordism to post-Fordism Turin found itself at the heart of the crisis. In 1981, while at the national level employment was increasing, in Turin there was a decrease of 17 thousands employees. [...] Between 1981 and 1989, while there were signals of concern regarding the progressive aging of the population, the Piedmontese productive sector lost about 200.000 employees. The manufacturing sector, the most penalized by the economic crisis and restructuring, expelled 150.000 workers" (Castagnoli 1998: 140-166). 
Italian "brothers" who directly employed them in their enterprises or offered contacts with owners of construction enterprises. The Romanian church didn't exist yet, so attending the Italian church was a way of building a network of relationship useful to seek employment: the church acted as a sort of recruitment agency.

When I arrived it was 1992, I was a boy, in Romania I worked in the factory for a short time, but I didn't have experience, because I was really young. I arrived in Turin and I had relatives from my family who were already here and gave me a place to sleep. My father was a pastor in Romania and he spoke to me about Italian pentecostals... I knew more or less that there were different groups, the Assemblies of God and so on... they are more libertine than we are. When I arrived in Turin I went to their church, but I didn't like it. Then I found independent churches where I felt more confortable. They helped us build our community (...). Concerning the job, I was fine with everything, when I arrived I didn't have documents and I stayed like this until the first sanatoria. At the beginning I found contacts for jobs through the Italian brothers of the Church, in Porta Palazzo. (M., August 2013)

Even if pentecostal migrants seemed to dispose of a higher social capital compared to the rest of Romanian migrants, by virtue of the faith network already existing in Turin at the time of their arrival, which they could easily access, this doesn't imply that they were exempt from exploitation, as underpaid undocumented workers.

I arrived in Turin in 1995, I was one of the first. But I suffered, you know, a lot. I broke concrete, they paid me 30.000 liras at the time. All day I broke concrete. It was heavy, too heavy. (M., November 2012)

\footnotetext{
"Ok, come tomorrow, I'll pay you 20 euros a day. Are you happy?" "Yes, thank you" "Ok, from tomorrow you come to work". I stayed with 20 euros, for more or less two years. It rained, snowed, it didn't matter. My first wage was 100 euros... after one month... because he told me "Listen, I want to regularize you, I need money to make the documents for you, if you want to pay, otherwise I don't want to pay for you, if you want the documents you pay for them". The law said something else... but he... we talked with closed doors, nobody listened. (G, June 2013)
}

With time, once the Romanian pentecostal church was established, some of the members were already salaried workers in small enterprises, other were themselves small entrepreneurs and so the recruitment started being organized within the community itself, through word of mouth, or though the intermediation of the pastor or other institutional figures, or via a showcase with job offers and demands placed at the entrance of the church.

When I arrived my brother already had a job, he worked in the construction sector. I also started, but not immediately. Some months passed, and I was desperate, I was sorry to have come. The church has been very useful in finding a job. To find a job, the pentecostal community was important. It's normal, because when you are alone you pray, but you are missing the un- 
ion, when there are a lot of people you pray and you know that tomorrow then... The other people give you strength. You know, you wait that God helps you, and in fact so it was. Little by little, we all found a job, we went to church, we worked. The Italian brothers gave us jobs, but also our own brothers! Directly or through their contacts. Let's say, my brother worked with calabresi, other brother worked with piemontesi, you understand? "You need someone? I have a good boy. Good, yes". And so we found places through word of mouth, because you know, in Italy it functions like this... and God worked for us. (D., August 2013)

Initially, migrants from Vicovu de Sus entered the construction labour market without previous experience, so the first insertion was characterized by training "on the job", "realized through coaching by more trained workers, which also involved an initial period of confinement to the most simple tasks, but also the toughest and most disqualified" (Cominelli 2005: 36). Towards the end of the 1990s, a phenomenon of self-entrepreneurship started to grow in the construction sector: it was often a kind of irregular labour, because it was linked to mechanisms of subcontracting operated by big enterprises in order to hide the presence of effective subordinate employment so as to gain profits by eroding labour costs (Allasino 2000). Migrants from Vicovu entered such a system similarly to the rest of the Romanian male migrant population in Turin, which tended to self-entrepreneurship towards the end of the 1990s. They soon became the migrant nationality that owned the largest number of construction enterprises, a position previously held by the Moroccan segment of the labour force. "[T] he percentage of Romanian construction entrepreneurs in Turin shifted from 2,3\% in 2000 to $21,1 \%$ in 2006" (Villosio, 2008:65).

To integrate within the mechanism of such a labour market, pentecostal migrants from Vicovu de Sus built first on the church as a recruitment agency, very effective to meet demand and supply, but also on several other dispositives. First of all, there was an entrepreneurial spirit and a work ethic based on a willingness to take risks, cultivated since the communist time, which found a favourable condition for expression within the capitalist system.

In our religion women can not be pastors, however they can study at University level to become theology teachers and I tell you: women learn the best! This is because they have a complex of inferiority. This is the same thing that happened with pentecostals. The first reason why we are having a lot of success now is that we were humiliated. We couldn't work in many sectors: army, education, medicine, police were not accessible to us. So after 1989 our reaction has been: «now I will show you where I can go». In Bukovina, Jewish people had the economic monopoly of the economy until communism. But God helps neo-protestantism and this is where we are now. The second reason why we are having success is that within the community we help each other. There is a lot of collaboration between business men. Another aspect is that we have better morals. In Vicovu de Sus from the economic point of view it is much better now than it was under communism. There has been a great exodus and this has brought change in the mentality. Pentecostals are the only ones who made good business in Bukovina. We created the 
economic basis mainly with the shoe industry. It is linked with the small entrepreneurial activities that we did during the late years of communism. (Simion Buzduga, october 2012)

Such a spirit in the context of Turin reified a discourse on entrepreneurship built upon a hierarchy of whiteness which tends to naturalize the economic - other than social and political - marginalization of certain segments of the population (Ferrero and Perocco, 2011). In fact the contemporary Italian space is traversed by racialization processes which also affect "Romanian" bodies, even after the integration within EU structures. As Grappi and Sacchetto argued "even white skin and freedom of mobility" do not guarantee the immunity from processes of racialization of semi-oriental difference, so that "'new' European citizens from countries of ex-realized socialism, after going through long phases of regulation and concession of the right to mobility, remain the object of stigmatization processes which show different lines of separation of whiteness" (Grappi and Sacchetto, 2013: 5). Along with juridical dispositives, institutional and mass media dispositives serve to keep "oriental" bodies in a condition of inferiority and deportability within the Italian national space ${ }^{27}$. Within the pentecostal discourse different technologies contributed to the construction of a pentecostal masculinity "whiter" than the dangerous and untrustworthy ordinary "Romanian man" and thus more apt for work and entrepreneurship. Among these, central is the rejection of alcohol.

\begin{abstract}
You know, many Romanians work in construction. Because of our religion, we respect each other. We do not steal, do not kill, we do not do strange things around... Drinking, we do not drink. I In fact I have spent years in Italy where while working they said: "Will you have a drink?" "No, no." "Not even wine?" "No, no." But they did not believe it. "It's true?" "Yes, look at this. You do not believe us, but that's how it is." (G, May 2013)

First of all the Bible says that wine makes you lose your head. Then in Proverbs chapter 23 , it says "Do not be with heavy drinkers of wine, or with gluttonous eaters of meat; For the heavy drinker and the glutton will come to poverty". It can kill you not in the physical sense, well also physical, but spiritual, because you lose your head. And then there is a cultural meaning, because the Romanians are people who drink a lot, but we have decided to eliminate really the use of all alcohol. You cannot make of your body whatever you want, otherwise you ruin it, using cigarettes for example, drugs or alcohol or anything that can deteriorate it. (L., August 2012)
\end{abstract}

\footnotetext{
27 'It is not by chance that in Italy the rhetoric of the 'Romanian rapist' becomes widespread right at the time of Romania joining the EU (in 2007), when it becomes necessary to find justifications to expel all of those citizens that the European legislation considers communitarian, but that in Italy are still disciplined by the media and institutions as foreigners" (Sabelli, 2012: 151).
} 
Along with bodily discipline comes the promotion of a strict lifestyle, disciplined-rational approach to work, savings, financial planning and discipline in handling family and personal finances. Second, the drive towards economic wealth is legitimized through an imaginary of material prosperity which colonized the local and national pentecostal imaginary after 1989. 
Here in Vicovu de Sus there were many changes: for example the search for material comfort, a change in lifestyle determined by material conditions. There is a Romanian saying that we have here in the village people that did everything to reach a wealthy lifestyle: "they split the devil in four". There are those who, migrating or aspiring to material wealth, got indebted at the bank, using as a collateral their house or their old parents' house. You know, those who see the bank as a goldmine, as a safety valve to maintain the appearance of wealth. Many also go to usurers to get the money. (...) So in the end who made the New Man, communism or capitalism? Where have you seen a New Man on earth? I'll tell you an anecdote: when you see elderly people, be it women or men, going to church with traditional clothes, well for them it doesn't matter that it is communism or capitalism, they have time for their spirit, but this is not the case anymore for young generations. (I., May 2013)

The work of God is realized through money and through the Holy Spirit. In Scripture there is a lot of talk about money and the necessity to sustain the ministry and the Church itself. The entrepreneurial spirit went so much forward that no Christian institution can go on without money. We are becoming dependent on money. We interpret it as a gift from the Holy Spirit through God's work. (R., March 2013)

The desire to make money is well valued within the community, and money is necessary for the growth of the church itself, where the practice of the tenth is established.

My fortune came along because of God's help. In 1997 I had some money saved and I decided to give to the church, I didn't make any profit that year. In 1998 I had doubled my profit, because of God's help. I gave everything in 1997 for the church and then I got double, triple that in return. (A., October 2012)

It is possible to argue that the Romanian pentecostal discourse has been influenced by the prosperity doctrine, in a political-economic context marked by radical change in the meaning of work and wealth. Third, if the pentecostal movement in Vicovu had historically developed through social diffusion among peasantry, in a context of structural change in the economy, labour migration favoured the construction of complex social stratification within the church itself, with the emergence, at the extremes, of a new class of entrepreneurs active mainly in the construction sector and a class of unskilled labour functionally at the disposal of the enterprises for salaried and on call jobs. Such a phenomenon was legitimized through the de-politicisation of class conflict and the internalization of power structures. Economic inequality is never thematised within the community, due to a rhetoric of "brotherhood" and of the opportunity for anybody to become successful self-entrepreneurs by God's will and with the help of the community. Such rhetoric is also promoted, besides sermons and biblical studies, through formal activities, such as conferences on how to organize a business for it to be profitable and on professionalization. 


\begin{abstract}
We tried to make the people understand that we are all equal. That even if there are poor people, the church can help you start your business: we can buy the tools for you and then you will pay us back. During such activities, we also tried to culturally intervene for a mentality of savings and investments. To explain to everyone how to become investors on their own. (L., July 2013)
\end{abstract}

These dispositives are well exemplified by the biographical trajectory of Vicovu de Sus's main businessman, P.C., owner of Sorelmid, a shoe-making company which in 2012 had a turnover of 10 million euros, over 600 salaried workers and a distribution chain of 35 shops all over Romania. P.C.'s activity started during the 1980s, in the context of the proliferation of a secondary economy more recently interpreted in terms of a "refrigerator socialism" (Poenaru, 2008). Such activities were tolerated by the communist regime to attenuate the effects of a political economy and of a culture of scarcity. He was able to capitalize on his entrepreneurial savoir-faire within the ambivalent logics of an "unregulated" market, whose role was not only deepened after 1989, but also re-signified. As Mollona argued, informal economic activities could be "strategies of survival by marginal labourers", but also "a tool of economic policy used by the state for tuning the local labour market to the fluctuations" (Mollona, 2005: 544-545) of a given economic sector. It is precisely the case of informal economic activities in Romania, which under Communism where linked to the people's needs "to acquire the basic products and to satisfy basic needs" (Poenaru, 2007: 56), but after 1989 became functional within a neoliberal context with "increasing levels of unemployment" and "the relatively new and 'weak' existence of formal institutions, laws and economic activities" (Kaneff and Pine, 2011: 10). In 1994 P.C. founded his company and the following year he bought some dismissed machinery from a factory which had been undersold to Italian entrepreneurs in the context of savage privatization which characterized the beginning of the 1990s. It was a logic of internal competition within the pentecostal community driven from a local redefinition of prosperity that enabled the growth of business. The pentecostal discourse promoted an imaginary in which it is God's will for believers to be rich and wealthy, thus inviting them to integrate themselves into a heavenly economy of abundance (Marshall, 1991; Ukah, 2005).

Nicolis, Lidoro, Sorelmid, Denis. The four companies started together, all at the same time. They are all from the pentecostal community. $100 \%$ only pentecostal people. Nicolis, Lidoro, Sorelmid are all from the same family basically. We help each other, but since [in capitalism] it is a different system, there is competition. We are all friends, we go to church together, we sing and pray together, but when it comes to business, it's business. (P.C., January 2013) 
Moreover, P.C.'s business was based on the presence of a disposable labour pool. The local shoe-making sector profits were based on a general labour precarisation, also because several small companies became linked industries for Italian producers who eroded labour costs even beyond local standards. As Scroccaro (2012:283) explains, in the North-East the average wage was around 206 euros according to 2008 INSSE data. In Vicovu de Sus, if the production cost for a shoe is 5 euros, the Italian contractor pays 6 euros, forcing the subcontracting industry to seek its profits through the erosion of labour costs 28 . Within such a context, Sorelmid gained the workers' loyalty offering slightly higher salaries, which oscillated between 330 euros and 400 euros. The pentecostal discourse was then mobilized within the company to depoliticize economic inequalities through a rhetoric of communality, which was materially enacted through common prayers every morning for the company as a blessed community, singing activities during lunch breaks in which P.C. himself played the accordion, the organization of company parties at P.C.'s cottage, and especially the recruitment of labour within the church itself where an imaginary of "P.C.s is one of us" and "anybody can become P.C." was ordinarily performed.

\section{Social factories: The pentecostal "virtuous woman" put at work}

L. is a 37 years old woman, who received her baptism in water as soon as she reached 18 years old. She has lived for over ten years in Turin, as a pioneer of migration inside her family. She was in fact the second to move, after her older brother, in the second half of the 1990s. During the years spent in Turin she worked first as a "badante" 29 , then as a domestic worker in different Italian families. Within the church in Turin, most bodies gendered as women who migrated from Vicovu de Sus were employed in unpaid domestic work within their own families, while four were also formally employed in paid domestic labour. The pioneers of migration were generally employed as "badanti", and in time a diversification in employment patterns occurred.

Women, if they have children, they stay at home, you know, they have work to do there. Otherwise women work as badanti, yes, especially the ones that arrived earlier. Others do cleaning, others work as domestic workers and others work as waitresses in restaurants. However, most of those who actually work are either domestic workers or caregivers. From Vicovu only four work, one in factory and three in cleaning. (N., November 2013)

\footnotetext{
28 "Pour faire face à cette précarité, le sous-traitant roumain ne peut que se focaliser sur les prix concurrentiels de sa main-d'œuvre et non pas sur un produit haut de gamme, car ses chaussures sont classiques, de balade, dont le processus de production est assez standardisé" (Scroccaro, 2012:284).

29 The Italian word for caretaker.
} 
A first aspect to be noticed is a trend of feminization of pentecostal migration (Ehrenreich and Hochschild, 2003; Vianello, 2009), also visible in the case of Pentecostal migration from Vicovu de Sus, since many women were pioneers of their families in departing, as it is was the case for L. Such trend is in line with the mutations in the global regime of mobility which has also affected flows from Romania, and especially from Moldavia ${ }^{30}$ (Piperno, 2007). In Italy and more generally in advanced capitalist countries - migrant women are particularly on demand on the domestic and care labour markets given the interplay between several social and economic factors such as the dismantling of fordist welfare systems, the pattern of population ageing, the gendered segmentation of local labour markets and the increase in female participation in salaried labour. The first women migrating from Vicovu de Sus thus took part in what has been conceptualized as "global care chains", intended as "personal links between people across the globe based on paid and unpaid work for caring" (Ehrenreich and Hochschild, 2003: 131). The pentecostal network was central in enabling the constitution of such chains, since the church functioned as a recruitment agency especially mobilizing its ties with autochthonous pentecostal communities in Turin.

Asking one or another, that was how we built knowledge and relationships, eh... Often they found a job for women. This happened in many churches. "Look, we found a job for a woman." "All women now have a job here, but I have a cousin, I have a relative in Romania". "Then bring her here." And they brought her here since she was a woman who could work, then after a while, in time, she also brought her husband. And the husband allowed the woman to go because he knew that she could find a job right away, he said "Yes, yes, go to work - go work as a caregiver - yes, you can stay there, live there, sleep, eat, everything with that lady. It's a good job." He would say: "We have the opportunity, so go there". There are so many cases like this, where the woman came first. (N., November 2013)

N.'s narrative exemplifies well the fact that domestic and care labour goes beyond a labour relation in that the worker is required to provide extra "emotional" and "intimate" labour, so that the boundaries between the worker and the job do not exist anymore. This is why care work has been defined as "job without boundaries" (Degiuli, 2007). The provision of such extra labour

\footnotetext{
30 "In Romania, according to the estimates of CURS (Centre for Urban and Rural Sociology) on a sample of 1,199 family units, the number of females appears to have doubled in just three years (between 2001 and 2004), going from $16.7 \%$ to $31 \%$ of total migration. The percentage of female migration in the Ukraine is similar, according to figures from the Ministry for Family. Strong female migration networks are even concentrated in specific areas. Ternopil in the Ukraine and Iaşi in Romania are cases in point. In these areas, according to local research, female migration flows currently account for $50 \%$ of total migration and, at least in the Ukraine, entirely account for the increased migration in recent years." (Piperno 2007: 1)
} 
requires certain burdening skills on the part of the worker, which the migrant women I encountered try to perform also by mobilizing pentecostal "technologies of gender" (de Lauretis, 1987). According to Degiuli, emotional labour "ranges from the simple yet demanding need to always display appropriate body and facial expressions to the more complicated need to devise strategies geared toward providing spiritual comfort" (Degiuli, 2007: 204), while intimate labour would involve "bodily and psychological intimacy: manipulating genitalia, wiping noses, lifting torsos, and feeding mouths, but also listening, talking, holding, and just being there" (Boris and Parrenas, 2010: 2).

The pentecostal discourse conveys a set of gender norms that contribute to the construction of a "virtuous woman", whose sexuality is restrained while her modesty and piety are celebrated. It is important to underline that within Romanian pentecostal theology there is a debate over Biblical interpretations of gender norms, as I had the chance to discuss at the Pentecostal Theological Institute in Bucharest. However, such theoretical discussions are certainly detached from the materiality of everyday life in the religious community of $\mathrm{Vi}$ covu which, as the rest of Bukovina, is historically characterized by a strong conservatism, whose influence is maintained also within the migrant community. This emerged clearly in a discussion about the influence of the Church of God's "practical commitments" on Bukovinean pentecostalism with Valeriu Andreiescu, one of the most prominent historians of Romanian Pentecostalism. The construction of a pentecostal "virtuous woman" - modest, hard-working, family and communityoriented (on a different cultural context see Eriksen, 2016) - which also emerged through specific technologies of the body concerning for instance the prohibition of consuming alcohol and tobacco, a conservative hair and clothing style - was mobilized in Turin within the domestic and care labour markets in opposition to a social imaginary of the "Romanian woman" associated with sexuality, seduction, fraud ${ }^{31}$. As Balcanu argued in her analysis of newspaper articles, especially after the murder of an Italian woman by a Romanian sex worker in 2007, "all of a sudden the Romanian women are all only criminals, demonic hookers that came in Italy only for killing or stealing Italian men from their wives and mothers" (Balcanu 2009: 11). Thus, if on one hand the participation in the labour market

31 The image of seductive and affectively manipulative Romanian badante has been a widespread sexist and racist representation in Italian media and popular discourse, especially around 2007 when Romanian accession to the EU was widely framed within the discourse of a "barbarian invasion" from the East. Of course, within such patriarchal imaginary, there are also a number of "positive" characteristics that with time have been ascribed to the "Romanian woman" body within the domestic and care labour markets, such as cultural proximity. As Degiuli argues: "Romanian women are highly valued because of their ability to learn the language due to similarities between Italian and Romanian and because they can legally work in the country" (Degiuli, 2016: 90). 
abroad implied a challenge and a transformation of gender relations which governed the pentecostal community in Vicovu (see Stan 2005 for orthodox and catholic communities), since through salaried employment migrant women could access an economic power and an independence previously unknown, on the other hand this was a result of the reinforcement and not the subversion of existing gender norms (Butler, 1990). In the narratives of the migrant women from Vicovu the mobilization of the religious discourse, in its materiality, emerged as a central element in their employment tactics, as L.'s words exemplify.

You know, as a badante first and as a domestic worker later, I always worked for catholic families and they didn't know anything about Pentecostalism. I never really talked about pocăință, no, but for them it was clear that I was different from other Romanian women, that I was more serious, more loyal, I didn't go after men, I was silly, I was all family and church and they knew it from the way I dressed, my habits, they could perceive my devotion and my faith and they were admired. Truly, you know! They always told me how I was different, that I was respectful and a trustworthy person. I never told them in detail about the church, but I know that if I had invited them to come, they would have. For them it wasn't a matter of Pentecostalism and Catholicism, they didn't know, but for them I simply looked as a more profound Christian. (L., January 2013)

A second, interrelated, aspect to be underlined is the role of women within the community and the way in which their bodies were put at work in the construction of a translocal welfare system. A male member of the church once explained to me that "to understand the role of the woman in our community you have to bear in mind one simple fact: Eve comes from Adam's rib". Within the pentecostal community the woman is conceived as hierarchically inferior to the man, who in turn is inferior to God. This conversation occurred while we were talking about domestic violence, a real issue within the community, and was meant to stress that exercising male authority should conform to God's norms, and those norms do not endorse violence and abuse. I would like to relate the re-enactment of a patriarchal economy ${ }^{32}$ within pentecostal migration in its materialization within unpaid domestic labour, central for social reproduction both within the family and within the church. As Silvia Federici underlined:

Women's refusal to define themselves as housewives made it possible to conceive the unpaid domestic work done by women as a specifically capitalist form of labour-production and a terrain of exploitation: the social factory where the workforce is daily reproduced (Federici, 2012: 185).

32 Patriarchy is of course not specific for pentecostal discourse: "The patriarchal regime was deeply rooted in the Romanian peasant family pattern and it was maintained under socialism. Even if women acceded to education and to paid work their position within Romanian society remained subaltern in relation to men, especially in the private sphere. Women's gender identity continued being constructed around the role of mother, to which that of worker was added" (Vianello, 2013:112). 
In a context were neoliberal reforms have progressively restructured the welfare State both in Italy (Bazzicalupo, 2008) and in Romania (Ban, 2011), labour migration came to play a central role both for daily reproduction of migrant workers in Turin and in sustaining social reproduction in Vicovu de Sus. As Bruno Meeus has brilliantly argued:

\begin{abstract}
The Romanian work migration system evolved as a response to the increased individual welfare risks caused by a particular form of Romanian neoliberalism. The system acted as a transnational labour market and was built up from the grassroots. Secondly, through its maturing, this migration system acted as a 'safety valve' in Romania. Geographical proximity of informal work opportunities for over two million Romanians meant that neoliberal principles could be built into the Romanian welfare system, making migrant work a key structural aspect. (Meeus, 2013: 177)
\end{abstract}

The pentecostal women I encountered were charged with a triple burden in this respect, migrating to integrate within the Italian labour markets as a response to the problems of social reproduction back at home, while at the same time ensuring through unpaid labour the social reproduction of their families and their community both in Turin and in Vicovu de Sus. Such a system of translocal welfare was once again sustained through gender norms based upon biblical passages, ascribing certain roles to women with respect to domesticity within the family and within the church, "holding that the patriarchal family of male headship and female subordination is the 'order of creation', mandated by God" (Ruther, 2001). Such an order, even if partially challenged in the context of migration, was maintained daily by the practices enacted by pastors and by the so-called "Department of relations with diaspora churches" at the level of Church Council. Conflicts and tensions within the family around gender norms, often related to cases of abuse or to dynamics arising by female migration, were often pacified through counselling so that the "holy" unit was maintained. If the breaking of Romanian family units within the context of migration has been an issue, the pentecostal family remained firmly at the heart of the translocal economy, because the possibility of a divorce was extremely low.

\title{
Conclusion
}

Mobilizing fragments of pentecostal migrant oral histories, this article narrowly focused on a few features related to production and reproduction within labour movements between Vicovu de Sus and Turin. The pentecostal discourse, through a self-sustained entrepreneurial drive and a strict gendered division of labour, seems to have fostered the creation of a self-organized translocal 
community which obeys rather than escapes the dynamics of exploitation and dispossession proper of Romania's peripheral incorporation "into contemporary global regimes of production, accumulation and division of labour" (Poenaru, 2013). Far from any mechanistic explanation of the relationship between pentecostalism and capitalism, this papers mobilized some elements to argue that pentecostal economies actively participate in the constitution of "neoliberalism from below" (Gago, 2015) in a more complex way than a dichotomous analytics of power in terms of domination/resistance would imply. Further analysis, for example on the inner mechanism of social and ethnic stratification, on the conservatory political orientation within the movement, or on the role of pentecostal discourse as a healing technology to both contain and revolt against the social suffering produced within the neoliberal order, would be profitable. Following E. P. Thompson in his seminal history from below of the "Wesleyan" experience within "The Making of the English Working Class" (1963), analysed both in terms of a mechanism of "psychic terror" towards the working class, but also in terms of a potentially insurrectionary discourse, one must refuse any determinism in analysing the pentecostal discourse in its relation to the economic. This paper thus calls for further attention to the constitutive ambiguity of such a relationship at the level of everyday processes of subjectivation (Bayart, 2008) of migrant workers within the particular historicities of (trans)local societies they cross.

\section{REFERENCES}

Allasino, E. (2000). Immigrati in Piemonte. Una panoramica sulla presenza degli stranieri nel territorio regionale. IRES, WP 143/2000.

Andreiescu, V. (2012). Istoria penticostalismului românesc. Oradea: Casa Cărții.

Andrijasevic, R., Sacchetto, D. (2016). From labour migration to labour mobility? The return of the multinational worker in Europe. Transfer: European Review of Labour and Research, 22(2): 219-231.

Anghel, R. (2013). Romanians in Western Europe. Lanham: Lexington Books.

Aubrée, M. (2003). Un néo-pentecôtisme Brésilien parmi les populations immigrées en Europe de l'Ouest. Anthropologie et Sociétés, 27(1):65-84.

Balcanu, A. (2009). Italian images of Romanian female immigrants : From sex-slaves to successful managers. Cultures in Transit 2, Jun 2009, Lyon, France.

Ban, C. (2009). Economic Transnationalism and its Ambiguities: The Case of Romanian Migration to Italy. International Migration, 50(6): 129-149.

Ban, C. (2011). Neoliberalism in Translation. Economic Ideas and Reforms in Spain and Romania. Ph.D. Thesis. University of Maryland.

Bayart, J.-F. (2008). Comparing from below. Sociétés politiques comparées, 1:1-25. 
Bazzicalupo, L. (2008). Dimensioni Politiche dell'impresa sociale. Impresa Sociale, 2 :63-81.

Beaumont, F. (2005). La frontière roumano-ukrainienne et le poids réel de la question des Minorités. Cybergeo, 303.

Berta, G. (2007). La questione settentrionale: economia e società in trasformazione. Milano: Feltrinelli.

Bleahu, A. (2004). Romanian migration to Spain: Motivations, networks and strategies. In D. Pop (ed.) New Patterns of Labour Migration in Central and Eastern Europe. Cluj Napoca: AMM.

Boris, E., Parrenas, R. S. (2010). Intimate Labors : Culture, Technologies, and the Politics of Care. Standford : Standford University Press.

Butler, J. (1990). Gender trouble. Feminism and the Subversion of Identity. New York: Routledge.

Carfagna, M., Pittau, F. (2003). Italia: 20 anni di regolarizzazioni. In Caritas (ed.). Dossier Statistico Immigrazione 2003. Roma: Anterem.

Castagnoli, A. (1998). Da Detroit a Lione. Trasformazione economica e governo locale a Turin (1970-1990). Milano: Franco Angeli.

Chelcea, L. (2002). Informal Credit, Money and Time in the Romanian Countryside. Paper presented at the Fourth Nordic Conference on the Anthropology of Post-Socialism, Copenhagen. http://www.anthrobase.com/Txt/C/Chelcea_L_01.htm (Accessed 07/10/2016).

Colombo, A., Sciortino, G. (2004). Gli immigrati in Italia. Bologna: Il Mulino.

Cominu, S., Musso, S. (2009). Società e lavoratori della conoscenza a Turin. In G. Berta (ed.) Società e lavoratori della conoscenza a Turin. Turin: Associazione Turin Internazionale.

De Genova, N. (2016). The "crisis" of the European border regime: Towards a Marxist theory of borders. International Socialism, 150: 31-54.

De Lauretis, T. (1987). Technologies of Gender: Essays on Theory, Film and Fiction. Bloomington: Indiana University Press.

Degiuli, F. (2007). A job with no boundaries: home eldercare work in Italy. European Journal of Women's Studies, 14(3): 193-207.

Degiuli, F. (2016). Caring for a living : migrant women, aging citizens and italian families. Oxford: Oxford University Press.

Ehrenreich, B., Hochschild, A. R. (2003). Global woman: Nannies, maids, and sex workers in the new economy. New York: Metropolitan Books.

Elrick, T., Ciobanu, O. (2009). Migration networks and policy impacts:. Insights from Romanian-Spanish migrations. Global Networks, 9(1): 100-116.

Eriksen, A. (2016). The virtuous woman and the holy nation : Femininity in the context of Pentecostal Christianity in Vanuatu. The Australian Journal of Anthropology, 27(2) :260-275.

Favell, A. and Nebe, T. (2009). East-West migration and the impact of EU enlargement. In A. Favell, E. Recchi (ed.) Pioneers of European Identity: Citizenship and Mobility in the EU. Cheltenham and Northampton: Edward Elgar Publishing.

Federici, S. (2012). The Unifinished Feminist Revolution. The Commoner, 15 : 185-197. 
Ferrero, M., Perocco, F. (2011). Razzismo al lavoro. Il sistema della discriminazione sul lavoro, la cornice giudirica, gli strumenti di tutela. Milano: Franco Angeli.

Foucault, M. (1976). Histoire de la Sexualité Vol 1: la volonté de savoir. Paris: Gallimard.

Foszto, L. (2009). Ritual revitalisation after socialism. Community, personhood, and conversion among Roma in a Transylvanian village. Berlin: LIT-Verlag.

Foszto, L., Kiss, D. (2013). Pentecostalism in Romania. La ricerca folklorica, 65: 51-64

Foucault, M. (1987). The ethic of care for the self as a practice of freedom: an interview with Michel Foucault on January 20, 1984. In R. Fornet-Batancourt, H. Becker, A. Gomez- Müller and J.D. Gauthier. Philosophy \& Social Criticism, 12(2-3): 112131.

Gago, V. (2015). Financialization of Popular Life and the Extractive Operations of Capital: A Perspective from Argentina. South-Atlantic Quarterly, 114(1): 11-28.

Gog, S. and Roth, M. (2012). The Roma People of Romania. In M. Palmer and S. Burgess (eds.) The Wiley-Blackwell Companion to Religion and Social Justice. Malden: Blackwell.

Grappi, G. and Sacchetto, D. (2013). La gestione e la produzione delle differenze: razza e razzismo nei processi lavorativi italiani. Studi culturali, 2: 315-322.

Gunder Frank, A. (1991). Transitional Ideological Modes: Feudalism, Capitalism, Socialism. Critique of Anthropology, 11(2): 171-188.

Horvath, I. (2008). The Culture of Migration of Rural Romanian Youth. Journal of Ethnic and Migration Studies, 34(5): 771-786.

Hüwelmeier, G. and Krause, K. (eds.). Traveling Spirits. Migrants, Markets, and Mobilities. Oxford, New York: Routledge.

Iordachi, C., Dobrincu, D. (2009). Transforming peasants, property and power : the collectivization of agriculture in Romania, 1949-1962. Budapest: CEU Press.

IRES Piemonte and FIERI (2011). Progetto D.I. Ter - Osservatorio sull'immigrazione in Piemonte. http://www.piemonteimmigrazione.it/site/components/com_mtree/ attachment.php?link_id=447\&cf_id=60 (Accessed 20/10/2016)

Kalb, D. and Halmai, G. (2011). Headlines of Nation, Subtext of Class. Working Class Populism and the Return of the Repressed in Neoliberal Europe. New York: Berghahn Books.

Kaneff, D., Pine, F. (2011). Global Connections and Emerging Inequalities in Europe. London: Anthem Press.

Kideckel, D. (2008). Getting by in Postsocialist Romania. Bloomington and Indianopolis: Indiana University Press.

Ludtke, A. (1995). The History of Everyday Life: Reconstructing Historical Experiences and Ways of Life. Princeton: Princeton University Press.

Marshall, R. (1991). Power in the Name of Jesus. Review of African Political Economy, $52: 21-38$.

Marshall, R. (2009). Political spiritualities: The pentecostal revolution in Nigeria. Chigaco: University of Chicago Press.

Meardi, G. (2012). Social Failures of EU Enlargement. A Case of Workers Voting with Their Feet. London: Routledge.

Meeus, B. (2013). Welfare through migrant work: What if the Romanian 'safety valve' closes?. Southeast European and Black Sea Studies, 13(2): 175-194. 
Mezzadra, S., Neilson, B. (2013). Border as Method, or, the Multiplication of Labour. Durham: Duke University Press.

Mitropoulos, A. (2007). Autonomy, Recognition, Movement. In S. Shukaitis, D. Graeber, and E. Biddle (eds) Constituent Imagination. Militant Investigations, Collective Theorization. Oakland: AK Press.

Mollona, M. (2005). Made in Sheffield. An Ethnography of Industrial Work and Politics. New York and Oxford: Berghahn Books.

Moulier-Boutang, Y. (1998). De l'esclavage au salariat. Economie historique du salariat bridé. Paris: PUF.

Neagoe-Pleşa, E., Pleşa, L. (2005). Cultele neoprotestante din România în perioada 19751989. In A. Petcu (ed.) Partidul, Securitatea şi Cultele, 1945-1989. Bucharest: Editura Nemira.

Papadopoulos, D., Stephenson, N., Tsianos, V. (2008). Escape Routes: Control and Subversion in the $21^{\text {st }}$ Century. London: Pluto.

Piperno, F. (2007). From Care Drain to Care Gain : Migration in Romania and Ukraine and the rise of transnational welfare. Development, 50: 63-68.

Poenaru, F. (2008). On the Socialist Balcony: State, Citizens and Ideology in a Romanian Neighborhood. Saarbrücken: VDM Verlag.

Poenaru, F. (2013). Contesting Illusion. History and Intellectual Class Struggle in PostCommunist Romania. Ph.D. Thesis. Central European University.

Polgár, A. (2012). '1989'. IDEA artă + societate / arts + society, 42: 141.

Potot, S. (2000). Mobilité en Europe. Etude de deux réseaux migratoires roumains. Sociologie Românească, 2: 101-119.

Radu, C. (2001). De la Crângeni-Teleorman spre Spania: antreprenoriat, adventism şi migraţie circulatorie. Sociologie Românească, 1-4: 215-231.

Razvan, S. (2005). Patterns and Socio-economic Consequences of International Labour Migration on Catholic and Orthodox Villages from Eastern Romania (Neamt Country). In T. Bárány, G. Pulay and I. Zakariás (eds.) A Tarkaság Dicsérete. Az Erasmus Kollégium Diákjainak Tanulmányai. Budapest: Erasmus Kollégium Alapítvány.

Reyneri, E. (1998). The role of the underground economy in irregular migration to Italy: cause or effect?. Journal of Ethnic and Migration Studies, 24(2): 313-331.

Rigo, E. (2007). Europa di confine. Trasformazioni della cittadinanza dell'Unione allargata. Roma: Meltemi.

Ruther, R. R. (2001). Christianity and the Making of the Modern Family. London: SCM Press.

Sabelli, S. (2012). Sessualità, razza, classe e migrazioni nella costruzione dell'italianità. In F. M. Cacciatore, G. Mocchi and S. Plastina (ed.) Percorsi di genere. Letteratura, Filosofia, Studi postcoloniali. Milano-Udine: Mimesis.

Sacchetto, D. (2011). Ai margini dell'Unione Europea: Spostamenti e Insediamenti a Oriente. Roma: Carocci.

Scroccaro, A. (2012). Des territoires aux territorialités multi-situées : réseaux de la production $d u$ " made in Italy » en Roumanie. Ph.D. Thesis. University of Padua

Stan, L. and Turcescu, L. (2007). Religion and Politics in Post-Communist Romania. Oxford: Oxford University Press. 
Stan, S., Erne, R. (2014). Explaining Romanian laborlabour migration: From development gaps to development trajectories. Labor History, 55(1): 21-46.

Tamás, G. M. (2009). Un Capitalism Pur si Simplu. In A. T. Sarbu and A. Polgár (eds.) Genealogii ale Postcomunismului. Cluj: Idea.

Tazzioli, M. (2013). Countermapping migration governmentality: Arab uprising and practices of migration across the Mediterranea. Ph.D. Thesis. Goldsmiths University.

Thompson, E. P. (1963). The Making of the English Working Class. New York: Vintage Books.

Tichindeleanu, O. (2010). Towards a critical theory of postcommunism. Radical Philosophy, 159: 26-32.

Țichindeleanu, O. (2011). Opening towards Eastern Skins, European Masks. In F. Fanon, Piele neagră, măşti albe. Cluj: TACT.

Ukah, A. F.-K. (2005). Those Who Trade With God Never Lose : The Economies of Pentecostal Activism in Nigeria. In T. Falola (ed.) Christianity and Social Change in Africa : Essays in Honour of J. D. Y. Peel. Durham: Carolina Academic Press.

Van Dijk, R. (2002). The Soul is the Stranger: Ghanaian Pentecostalism and the Diasporic Contestation of 'Flow' and 'Individuality'. Culture and Religion, 3(1): 49-67.

Van Dijk, R. (2009). Social Catapulting and the Spirit of Entrepreneurialism: Migrants, Private Initiative and the Pentecostal Ethic in Botswana. In G. Huwelmeier and K. Krause (eds.) Traveling Spirits. Migrants, Markets and Mobilities. New York: Routledge.

Verdery, K. (1996). What Was Socialism, and What Comes Next? Princeton: Princeton University Press.

Vianello, A. (2009). Migrando sole. Legami transnazionali tra Ucraina e Italia. Milano: Franco Angeli.

Vianello, A. (2013). Moldovan, Romanian and Ukrainian Transnational Families Seen Through Women's Eyes. In M.-S. Alexandru, M. Nicolaescu and H. Smith (eds.) Between History and Personal Narrative : East-European Women's Stories of Migration in the New Millennium. Berlin-Vienna: LIT Verlag.

Villosio, C. (2008). La situazione e la recente dinamica. In FIERI (ed.) L'immigrazione che intraprende. Nuovi attori economici in provincia di Turin. Turin: Camera di Commercio, Industria, Artigianato e Agricoltura di Turin.

Vlase, I. (2004). Hommes et femmes en migration: d'un village roumain à Rome. Migration/Société, 93-94: 47-60.

Wanner, C. (2007). Communities of the Converted, Ukrainians and Global Evangelism. Ithaca: Cornell University Press.

Woolfson, C. (2007). Labour Standards and Labour Migration in the New Europe: PostCommunist Legacies and Perspectives. European Journal of Industrial Relations, 13(2): 199-218. 